\title{
Impact of Organisational Politics on Employee Turnover and Employee Performance
}

\author{
Dr. Namrata Gupta ${ }^{1}$, Mayank Singhal ${ }^{2}$, Dr. Sunita Chauhan ${ }^{3}$ \\ ${ }^{1}$ Assistant Professor in Management, MITS, Gwalior, Madhya Pradesh, India \\ ${ }^{2,3}$ Assistant Professor in Management, Aditya College, Madhya Pradesh, India \\ *Correspondence: Namrata Gupta; Email: drnamrata0751@gmail.com
}

\begin{abstract}
The Power is one's ability to influence other people. Influence is the process of affecting the person mentally or emotionally. When employees in an organization convert their powers into action politics comes into existence. Those with good political skills have the ability to use their bases of power vigorously. Politics concerns to the ways people gain and use power. Thus, organizational politics means the use of energy, strength and influence in organizations. Many researches have been conducted in various sectors to demonstrate the impact of Organizational Politics (OP).
\end{abstract}

The aim of this study was to find the impact of organizational politics on employee turnover \& employee performance in case of private sector banks. This study also finds out various factors underlying employee turnover \& employee performance. To achieve the object of the study questionnaire survey was used. The results show that there is a significant impact of Organizational Politics on Employee Turnover but there is no significant impact of Organizational Politics on Employee Performance among private bank employees.

Keywords: Organizational Politics, Employee Turnover, Employee Performance, Job Performance.

\section{ARTICLE INFORMATION}

Author(s): Dr. Namrata Gupta, Mayank Singhal and Dr. Sunita Chauhan Received: 17 Jan, 2021; Accepted: 02 Feb, 2021; Published: 25 July, 2021; e-ISSN: 2347-4696;

Paper Id: IJBMR-2021-20;

Citation: 1037391/IJBMR.090301

Webpage-link:

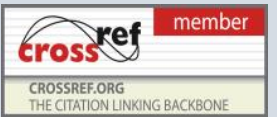

https://ijbmr.forexjournal.co.in/archive/volume-9/ijbmr-090301.html

\section{INTRODUCTION}

\subsection{Organizational Politics (OP)}

Studies described that politics is like an epidemic in organizations and it behoove much attention and verifiable examination (e.g., Gandz \& Murray, 1980; Mayes \& Allen, 1977; Mintzberg, 1983; Pfeiffer, 1981, 1992). The importance of organizational politics (OP) lies in its probable results and effect on work outcomes. Theoretical arguments explain that politics often obstruct with normal organizational processes (e.g., decision making, promotion, and rewards) and damages the productivity and performance both at individual and organizational levels. Experimental attempts to support this notion have proved equivocal. Some studies explained a unassertive relationship of OP to job attitudes or stress-related responses (e.g., Drory, 1993; Ferris et al., 1996a, 1996b). More modern works expressed that politics enhances withdrawal behaviors and turnover intentions (e.g.,Cropanzano, Howes, Grandey, \& Toth, 1997), but others found no such relationship (e.g., Parker, Dipboye, \& Jackson, 1995). All these studies overlooked the relationship between OP and other possible work outcomes, such as direct negligent behavior and actual employee performance. While perceptiveness of organizational politics play an important role in the organization, relatively little is known about this process
(Ferris, Russ \& Fandt, 1989).Given the pervasiveness and importance of organizational politics in the job sector, this phenomenon needs to be examined more extensively. Knowledge accumulated from organizational politics research will enable managers better to understand, predict and manage political behaviors encountered in organizations.

Therefore keeping in view the importance of organizational politics we have made an attempt to study about the outcomes of organizational politics.

This definition was provided by Mayes and Allen (1977) which is as: "Organizational politics is the management of effect to get ends not sanctioned by the organization or to obtain sanctioned ends through non-sanctioned influence means." Sue Jones (1978), University of Bath, in "Organizational politics - only the darker side?" explained politics as "the activity which persons accept in chase of certain personally valuable outcomes to affect others whom they see as having the power of different kinds to facility or hinder those outcomes and also different and feasible conflicting concerns to their own". According to Mangham 1979; politics is the struggle of suitable men to have what they consider to be right and proper preponderate. Gandz and Murray, 1980; Porter, Allen and Angle, 1981) which may be deleterious to organizational objects or to the interests of others in the organization (e.g., Ferris et al., 1989; Gandz and Murray, 1980; Porter et al., 1981).Organizational politics described to conduct "that occur on an unceremonious basis within an organization and contain worldwide acts of influence that are designed to save sole professional careers when conflicting courses of work are possible" (Drory, 1993; Porter, Allen, \& Angle, 1981.

\subsection{Employee Turnover}

Employee turnover has been stated by Price (1977) as the 
action of members across the boundary of an organization. As Mobley (1982) found that turnover is the voluntary cessation of membership in an organization by an individual who receives financial compensation for sharing in that organization. Furthermore, employee turnover is separation from an organization and not includes promotion, transfer, or other internal movements within an organization. Lane (2001) explained employee turnover as the outcomes of both quits and layoffs and further states that some turnover is a result of jobs in one firm being demolished and jobs in another firm being created and hence due to the reallocation of jobs across the economy in response to changes in demand. From the descriptions above, we conclude that employee turnover is when employees leave their employment permanently and the entrance of new employees to the organization. That employee yield can either be positive or negative, but all have a significant impact on productivity (Boxall and Baldwin, 2002). According to Mitchell et al (2001), employee turnover apply extensive cost both the individual and the organization level. At independent level, it does not matter if the person leaves voluntarily to another job or is forced to leave and take a personal toll. For organization level, the problem arises when leaving employees take their valuable knowledge and expertise gained through experience with them.

\subsection{Employee Performance}

Employee achievement is described as the result of employees to make them attain goal (Herbert, John \& Lee 2000) while performance may be used to define what an organization has adept with respect to the process, outcome, relevance and success. Employee presentation can be manifested in improvement in production, easiness in using the new technology, highly motivated workers. Employee achievement is normally looked at in terms of outcomes. Although it can also be looked at in terms of behavior (Armstrong 2000). Kenney et al. (1992) found that employee's performance is measured against the performance standards set by the organization. There are lots of unit that can be taken into concern when measuring performance for instance using of productivity, efficiency, effectiveness, quality and profitability measures (Ahuja 1992). Many researches on productivity of workers has showed that employees who are satisfied with their job will have higher job performance, and thus supreme job retention, than those who are not happy with their jobs (Landy 1985). Kinicki \& Kreitner (2007) documents that employee's performance is higher in happy and satisfactory workers and the management finds it easy to motivate high performers to obtain firm targets.

\section{LITERATURE REVIEW}

Gerald R.Ferris, K.Michele Kacmar (1992) empirically tested the model of Organizational politics and found out that job involvement \& satisfaction were influenced by Organizational Politics perceptions which are formed due to Organizational, environmental and personal factors and in turn impact the organizational outcomes such as job involvement, Job anxiety, job satisfaction and withdrawal from the organization. Patricia A. Wilson (1995) found the effects of power and politics on organizational commitment. Politics and power explained to have a prominent effect on the organizational commitment of managerial. Gerald.R.Ferris, Dwight.D.Frink (1996) studied Politics as a feasible source of stress in the work environment. It fully supported the notion of organizational politics as a source of stress in the work environment and how it impacts on psychological strains of individuals. Wayne.A.Horchwarter, Pamela.L.Perrewe, Gerald.R.ferris Rachel Guererio (1999) found that there is a positive relationship between organizational politics and job tension. Job tension reduced as organizational commitment increased and the positive relationship between organizational politics and intent to turnover decreased as organizational commitment increased. Martha.C.Andrews, L.A.Witt and K. Michele Kacmar (2001) examined the quite effect of exchange principles on the relation between perception of organizational politics and manager ratings of retention. They found out that employee's perception of organizational politics is negatively related to manager assessments of retention. Eran Vigoda (2002) examined direct and indirect/mediating relationships among Job distress \& organizational politics and found that Job distress was an immediate response to organizational politics. Job risk proved a capacity moderator between organizational politics and aggressive behavior as enacted by the employees themselves. June M L Poon (2003) found that the perceptions of organizational politics have psychological and attitudinal consequences for employees in the form of job stress, job satisfaction and turnover intention. They further stated that employees will perceive their work environment to be politically charged if they believe that they have lack of information about job objectives, job responsibilities, and consequence of job performance; resources are limited in their workplace; and trust levels are low among organizational members.

The review of literature broadly interacts with the varying definitions of organizational politics as well as employee perceptions of environments which are viewed as political.

\section{OBJECTIVES OF THE STUDY}

1. To design, develop and standardize a measure to evaluate organizational politics employee turnover and employee performance.

2. To find out various factors underlying organizational politics employee turnover and employee performance.

3. To study the impact of organizational politics on employee turnover and employee performance among employees of private banks.

4. To identify new areas for further research.

\subsection{Hypothesis Framed}

H01 There is no significant impact of organizational politics on employee turnover.

H02 There is no significant impact of organizational politics on employee performance 


\section{RESEARCH METHODOLOGY}

The Study: The study was exploratory in nature and aimed to explore various factors influencing organizational politics, employee turnover and employee performance among private banking sector employees and to find out the impact of organizational politics on employee turnover and employee performance among employees of private banks.

\subsection{Sample Design}

Sample Population: The sample population was all the employees working in private banks in Gwalior region.

Sample Size: The sample size was 300 employees working in various private banks of Gwalior region.

Sampling Element: The sampling element was individual employees working in private banks of Gwalior region.

Sampling Technique: In this study, judgmental (nonprobability) sampling technique was used.

\subsection{Data Collection and Measurement Scale}

The data was collected from the employees working in various private banks in Gwalior region. The study was based on primary data. The instrument for data collection was a selfdesigned questionnaire which was administered both personally and via emails to the employees working in banking sector to collect the data. Questionnaire was based on 5-point "Likert" scale ranging from 1= Strongly Disagree to 5= Strongly Agree.

\subsection{Data Analysis and Interpretation}

Statistical software SPSS version 22 has been used for data analysis. Item to total correlation was used to establish the internal consistency of the questionnaire, Cronbach's alpha was used to measure the reliability of the measurement scale. Factor analysis was used to find out the various factors underlying organizational politics, employee turnover and employee performance. Regression analysis was applied to find out the impact of organizational politics (independent variable) on employee turnover \& employees performance (dependent variable).

\section{RESULTS \& DISCUSSION}

After studying the data of 300 private bank employees, by applying the statistical tools following results were found:

\subsection{Consistency Measure}

Constancy of all the factors in the questionnaire was checked through item to total correlation. In this correlation of every item with the total was measured and the computed value was compared with standard value. Only those factors were accepted whose value was more than the standard value.

\subsection{Reliability Measure}

Organizational Politics: Reliability of the measure was tested using SPSS software and the Cronbach's Alpha value was found to be 0.728 .

Employee Turnover: Reliability of the measure was tested using SPSS software and the Cronbach's Alpha value was found to be 0.753 .

Employee Performance: Reliability of the measure was tested using SPSS software and the Cronbach's Alpha value was found to be 0.653 .

\subsection{Validity}

The Validity of the measure was established using face validity which was found to be high.

\subsection{Factor Analysis (Organizational Politics)}

The raw scores of 12 items were subjected to factor analysis to find out the factors that contributed towards Organizational Politics. After factor analysis, three factors are identified. The factors were Nepotism, Organizational Support and Management Control.

5.4.1 Nepotism (4.509): This factor has emerged as the most important determinant of Organizational Politics with $37.575 \%$ of variance. The major elements constituting this factor include; Favouritism (0.398), Promotion given to friends and acquaintances (0.633), Discomfort with Subordinates related to high level executives (0.736), System favouring Single mind decision (0.825), Presence of Influential group of staff (0.850), Management putting their self-interest into allocation of resources (0.543), Some groups build themselves by putting others down (0.716) \& Fair pay and promotion (0.555).

5.4.2 Organizational Support (1.444): This factor has emerged as an important determinant of Organizational Politics with $12.033 \%$ of variance. The major elements constituting this factor include; Organization cares about employee's well-being (0.774), Career Development (0.747) \& Help available from organisation (0.732).

5.4.3 Management Control (1.086): This factor has emerged as an important determinant of Organizational Politics with $9.05 \%$ of variance. The major elements constituting this factor include; Monopolization of Ideas, practices, activities $(0.855)$.

\subsection{Factor Analysis (Employee Turnover)}

The raw scores of 9 items were subjected to factor analysis to find out the factors that contributed towards Employee Performance. After factor analysis, three factors are identified. The factors were Employee Satisfaction, Working Environment and Employee Motivation.

5.5.1. Employee Dis-Interest (3.039): This factor has emerged as the most important determinant of employee turnover with $43.420 \%$ of variance. The major elements constituting this 
factor include; Interest in job offers in the newspaper (0.596), put less efforts in work (0.837), Postpone important duties $(0.737) \&$ do not work hard in my job (0.855).

5.5.2. Turnover Intention (1.259): This factor has emerged as an important determinant of employee turnover with $17.988 \%$ of variance. The major elements constituting this factor include; Think of leaving my job (0.790), job worth (0.819) \& will not stay much longer in this organization $(0.510)$.

\subsection{Factor Analysis (Employee Performance)}

The raw scores of 9 items were subjected to factor analysis to find out the factors that contributed towards Employee Performance. After factor analysis, three factors are identified. The factors were Employee Satisfaction, Working Environment and Employee Motivation.

5.6.1 Employee Satisfaction (2.130): This factor has emerged as the most important determinant of employee performance with $23.664 \%$ of variance. The major elements constituting this factor include; increase in level of productivity (0.694), encouragement to come up with new ideas (0.700) \& feeling of personal accomplishment (0.632).

5.6.2 Working Environment (1.345): This factor has emerged as an important determinant of employee performance with $14.939 \%$ of variance. The major elements constituting this factor include; working environment is influenced by mind games (0.488), Working environment affects performance (0.784) \& Working environment give sense of motivation (0.629).

5.6.3 Employee Motivation (1.327): This factor has emerged as an important determinant of employee performance with $14.744 \%$ of variance. The major elements constituting this factor include; Involvement in decision making (0.698), Reward given for the work (0.661) \& feel motivated to see company succeed (0.734).

\subsection{Hypothesis Testing}

H01: There is no significant impact of organizational politics on employee turnover.

Model Summary

\begin{tabular}{|l|l|l|l|l|l|}
\hline Model & $R$ & R Square & Adjusted R Square & $\begin{array}{l}\text { Std. Error of the } \\
\text { Estimate }\end{array}$ & Dubin-Watson \\
\hline 1 & $.641^{\mathrm{a}}$ & .411 & .409 & 2.95750 & 1.846 \\
\hline
\end{tabular}

a. Predictors: (Constant), Org.Politics

b. Dependent Variable: emp.Tumover

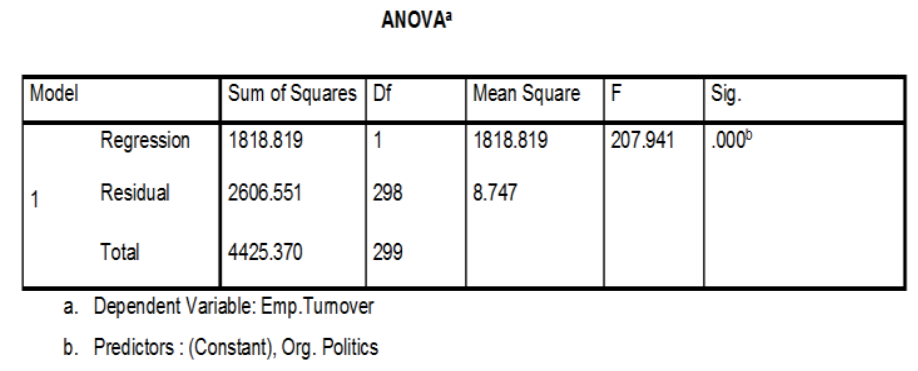

Regression analysis was applied between Organizational Politics (independent variable) and Employee Turnover (dependent variable) among private bank employees. The results of regression indicate that independent variable (Organisational Politics) has significant relationship with dependent variable (employee turnover) The results of regression indicates that Organizational Politics has a significant relationship with Employee Turnover.

H02: There is no significant impact of organizational politics on employee performance.

Model Summary

\begin{tabular}{|l|l|l|l|l|l|}
\hline Model & $R$ & $R$ Square & $\begin{array}{l}\text { Adjusted } \\
\text { Square }\end{array}$ & $\begin{array}{l}\text { Std. Error of the } \\
\text { Estimate }\end{array}$ & Durbin-Watson \\
\hline 1 & $.035^{\mathrm{a}}$ & .001 & -.002 & 2.36541 & 1.771 \\
\hline
\end{tabular}

a. Predictors: (Constant), Org.Politics

b. Dependent Variable: Emp.performance

ANOVA ${ }^{\mathrm{a}}$

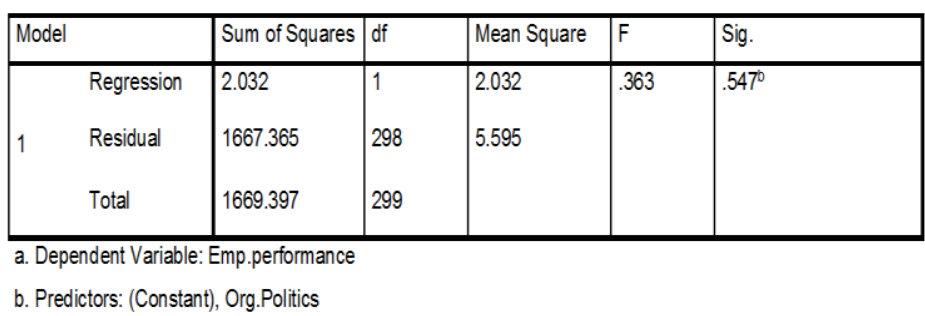

Regression analysis was applied between Organizational Politics (independent variable) and Employee Performance (dependent variable) among private bank employees. The results of regression indicate that independent variable (Organizational Politics) has no significant relationship with dependent variable (Employee Performance).

Therefore, the null hypothesis that there is no significant impact of Organizational Politics on Employee Turnover is not rejected.

\section{CONCLUSION}

The objectives of the study were to find out the impact of Organizational Politics on Employee Turnover and Employee Performance among private bank employees and to find out 
the various factors underlying Organizational Politics, Employee Turnover \& Employee Performance. The findings of the research conclude that there is a significant impact of Organizational Politics on Employee Turnover but there is no significant impact of Organizational Politics on Employee Performance among private bank employees. The underlying factors of Organizational Politics emerged from this study are Nepotism, Organizational Support and Management Control. The underlying factors of Employee Turnover emerged from this study are Employee Dis-interest and Turnover Intention. The underlying factors of Employee Performance emerged from this study are Employee Satisfaction, Working Environment and Employee Motivation.

\section{REFERENCES}

[1] Gandz, J., \& Murray, V. V. (1980). The experience of workplace politics. Academy of Management Journal, 23, 237-251.

[2] Mintzberg, H. (1983). Power in and around organizations. Englewood Cliffs, NJ: Prentice Hall.

[3] Parker, C. P., Dipboye, R. L., \& Jackson, S. L. (1995). Perceptions of organizational politics: An investigation of antecedents and consequences. Journal of Management, 21, 891-912.

[4] Pfeffer, J. (1981). Power in organizations. Marshfield, MA: Pitman Cropanzano, R., Howes, J. C., Grandey, A. A., \& Toth, P. (1997). The relationship of organizational politics and support to work behaviors, attitudes, and stress. Journal of Organizational Behavior, 18, 159-180.

[5] Ferris, G. R., \& Kacmar, K. M. (1992). Perceptions of organizational politics. Journal of Management, 18, 93-116.

[6] Drory, A. (1993). Perceived political climate and job attitudes. Organizational Studies, 14, 59-71.

[7] Ferris, G. R., Frink, D. D., Bhawuk, D. P. S., \& Zhou, J. (1996a). Reactions of diverse groups to politics in the workplace. Journal of Management, 22, 23-44.

[8] Ferris, G. R., Frink, D. D., Galang, M. C., Zhou, J., Kacmar, M. K., \& Howard, J. L. (1996b). Perceptions of organizational politics: Prediction, stress-related implications, and outcomes. Human Relations, 49, 233-266.

[9] Mayes, B. T., \& Allen, R. W. (1977). Toward a definition of organizational politics. Academy of Management Review, 2, 672-678.

[10] Ferris, G.R., Russ, G.S. and Fandt, P.M. (1989) „Politics in organizations $^{\text {ee, }}$ in R.A. Giacalone and P. Rosenfeld (eds) Impression management in the organization, Hillsdale, NJ: Lawrence Erlbaum: 143-70.

[11] Price, J.L (1977). The study of turnover, 1st edition, Iowa state university press, IA pp10-25

[12] Drory, A., \& Romm, T., (1988). Politics in organization and its perception within the organization. Organization Studies. 9(2). 165179.

[13] Ferris G. R., \& Kacmar, K. M. (1992). Perceptions of organizational politics. Journal of Management. 18(1). 93-116.

[14] Drory, A. (1993). Perceived Political Climate and Job Attitudes. Organization Studies, 14(1), 59-71.

[15] Patricia A.Wilson (1995), "The effects of Politics and Power on the Organisational Commitment of Federal Executives", Journal of Management, vol 21, No 1, 101118
[16] Ferris, G.R., Frink, D.D., Galang, M.C., Zhou, J., Kacmar, M.K. and Howard, J.L. (1996b) „Perceptions of organizational politics: prediction, stress-related implications, and outcomes ${ }^{\text {ee }}$, Human Relations, vol 49: 233- 66.

[17] Ferris.G.R, Dwight.D.Frink (1996), "Perception of Organisational Politics: prediction, stress-related Implications and Outcomes", Human Relations, Vol 49, No 2.

[18] Michele Kacmar, Dawn S. Carlson (1997), "K. Michele Kacmar,Dawn S. Carlson, "Further Va Lida T/On Of The Perceptions Of Politics Scale (Pops): A Multiple Sample Investigation", Journal Of Management ,1997, Vol. 23, No. 5, 627-658"

[19] Wayne.A.Horchwarter, Pamela.L.Perrewe, Gerald.R.ferris Rachel Guererio (1999), "Commitment as an antidote to the tension and turnover consequences of Organisational Politics"; Journal of Vocational Behaviour 55, Eran Vigoda (2000), “Eran Vigoda, "Organizational Politics, Job Attitudes, and Work Outcomes: Exploration and Implications for the Public Sector", Journal of Vocational Behavior 57, 326-347

[20] EranVigoda (2002), "Stress-Related Aftermaths to workplace politics: The Relationships among Politics, Job Distress and Aggressive Behaviour in Organisations", Journal of Organisational Behaviour, Chichester Aug 2002. Vol 23, Iss:5,pg571

[21] Martha.C.Andrews, L.A.Witt and K.Michele Kacmar (2001), "The interactive effects of Organisational Politics and exchange ideology on manager ratings of retention".

[22] Wayne A.Horchwarter (2003), "The interactive effect of negative and positive effect on the politics perception-Job Satisfaction Relationship"; Journal of Management.

[23] Samuel Aryee, Zhen Xiong Chen and Pawan.S.Budhwar (2004), "Exchange Fairness and Employee Performance: An examination of the relationship between organizational politics and Procedural Justice"; Organisational Behaviour and Human Decision Processes 94-1-14.

[24] Eran Vigoda-Gadot and Danit Kapun (2005), "Eran VigodaGadot and Danit Kapun, "Perceptions of politics and perceived performance in public and private organisations: a test of one model across two sectors", The Policy Press.

[25] Kenneth.J.Harris, Martha.C.andrews \& K.Michele Kacmar (2007), ““'The Moderating Effects of Justice on the Relationship Between Organizational Politics and Workplace Attitudes", J Bus Psychol

[26] Brian K. Miller A. Matthew A. Rutherford /Robert W. Kolodinsky (2008), ““’Perceptions of Organizational Politics: A Meta-analysis of Outcomes"e, J Bus Psychol (2008) 22:209222 ".

[27] Rozhan Othman (2008), "Organisational Politics: The Role Of Justice,Trust And Job Ambiguity", Singapore Management Review, Volume 30 No 1- Singapore Management Review; 2008; 30, 1; Abi/Inform Global Pg. 43"

[28] Rozhan Othman (2008), "Organisational Politics: The Role Of Justice,Trust And Job Ambiguity", Singapore Management Review, Volume 30 No 1- Singapore Management Review; 2008; 30, 1; Abi/Inform Global Pg. 43"

[29] Hsing-Chu Chen, Cheng-I Chu, Ying-Hui Wang, Ling-Chu Lin(2008), "Turnover factors revisited: A longitudinal study of Taiwanbased staff nurses"

[30] Gloria Harrell-Cook, Gerald R Ferris, James H Dulebohn, "Political behaviors as moderators of the perceptions of 
organizational politics - work outcomes relationships", Journal of Organizational Behavior. Chichester: Dec 1999. Vol. 20, Iss. 7; pg. 1093.

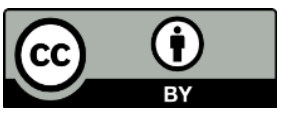

2021 by the Dr. Namrata Gupta, Mayank Singhal and Dr. Sunita Chauhan. Submitted for possible open access publication under the terms and conditions of the Creative Commons Attribution (CC BY) license (http://creativecommons.org/licenses/by/4.0/). 